\title{
Kelakai Sebagai Antianemia
}

Putri Eka Yulianthima

SMA Negeri 2 Sampit, Kotawaringin Timur, Kalimantan Tengah, Indonesia

\begin{abstract}
Abstrak. Kelakai adalah salah satu tumbuhan jenis paku-pakuan. Kelakai termasuk tumbuhan yang mudah ditemukan di daerah tanah gambut seperti di Kalimantan Tengah. Berdasarkan hasil penelitian tahun 2005 yang dilakukan oleh Hayinah, dkk, Jurusan Budidaya Pertanian, Universitas Lambung Mangkurat, Banjarbaru, kandungan zat besi yang terdapat di dalam kelakai yaitu 291,32 mg per 100 g. Kekurangan darah atau anemia adalah keadaan dimana rendahnya hemoglobin yang dapat menyebabkan produksi eritrosit rendah. Inti molekul hemoglobin adalah zat besi (Fe). Sehingga, kekurangan zat besi menjadi salah satu faktor penyebab anemia. Hal ini akan menyebabkan berbagai gejala anemia seperti mudah letih, lesu, wajah pucat, pusing, daya tahan tubuh menurun, dan detak jantung lebih cepat. Adanya zat besi pada kelakai dapat meningkatkan kadar hemoglobin dalam tubuh sehingga membantu mengurangi gejala penderita anemia. Metode yang digunakan dalam penulisan karya tulis ini adalah deskriftif. Penulis hanya menganalisis fakta-fakta yang sudah ada dalam kehidupan seharihari masyarakat sekitar tentang cara mengatasi anemia dengan memanfaatkan tumbuhan kelakai.
\end{abstract}

Kata kunci: anti anemia, kelakai

\section{PENDAHULUAN}

Lemidi, lemiding, atau ramiding (Stenochlaena palustris) adalah sejenis paku-pakuan anggota suku Blechnaceae. Pucuk dan daun muda pakis ini biasa dijadikan sayuran di berbagai wilayah sebarannya. Karena itu, paku ini juga dikenal dengan banyak nama seperti miding, melat, akar pakis, lambiding, lamidin, pau para, paku limbeh, paku hurang, paku bang. Di Kalimantan Tengah dan Kalimantan Selatan tumbuhan ini disebut kelakai.

Klasifikasi ilmiah :

\begin{tabular}{|l|l|}
\hline Kerajaan & Plantae \\
\hline Divisi & Pteridophyta \\
\hline Kelas & Pteridopsida \\
\hline Ordo & Blechnales \\
\hline Famili & Blechnaceae \\
\hline Genus & Stenochlaena \\
\hline Spesies & S. palustris \\
\hline Nama biominal & Stenochlaena palustris \\
\hline
\end{tabular}

(Wikipedia,(online)https://id.m.wikipedia.org/wiki/Lemidi, diakses tanggal 7 November 2017)

Kelakai tumbuhan yang mudah ditemukan di daerah tanah gambut seperti di Kalimantan Tengah. Berdasarkan hasil penelitian tahun 2005 yang dilakukan oleh Hayinah, dkk, Jurusan Budidaya Pertanian, Universitas Lambung Mangkurat, 
Banjarbaru, kandungan zat besi yang terdapat di dalam kelakai yaitu 291,32 mg per $100 \mathrm{~g}$.

Dalam tubuh manusia zat besi berfungsi sebagai pengangkut oksigen dari paru-paru ke jaringan dan mengangkut elektron di dalam proses pembentukan energi di dalam sel. (Wikipedia,(online) https://id.m.wikipedia.org/wiki/Zat-besi, diakses tanggal 7 November 2017). Untuk mengangkut oksigen, zat besi harus bergabung bersama protein untuk membentuk hemoglobin di dalam sel darah merah.

Kekurangan darah atau anemia adalah keadaan dimana rendahnya hemoglobin yang dapat menyebabkan produksi eritrosit rendah. Inti molekul hemoglobin adalah zat besi (Fe). Sehingga, kekurangan zat besi menjadi salah satu faktor penyebab anemia. Hal ini akan menyebabkan berbagai gejala anemia seperti mudah letih, lesu, wajah pucat, pusing, daya tahan tubuh menurun, dan detak jantung lebih cepat.

Adanya zat besi pada kelakai dapat membantu meningkatkan kadar hemoglobin dalam tubuh sehingga membantu mengurangi gejala penderita anemia. Pucuk dan daun muda pakis ini biasa dijadikan sayuran. Masyarakat kalimantan tengah biasanya mengolah kelakai dengan cara direbus atau ditumis. Proses ini memerlukan waktu yang tidak terlalu lama dengan cara memasak kelakai yang telah dibersihkan hingga batang kelakai lunak.

Namun, kelakai yang telah dimasak tidak dapat disimpan dalam jangka waktu yang lama. Selain itu, pada keadaan tertentu penderita anemia memerlukan obat yang dapat disimpan dan dibawa ke manapun agar sewaktu - waktu penderita mengalami gejala anemia, dapat diatasi dengan segera.

Penulis ingin mengetahui apakah serbuk kelakai kering dapat dibuat kapsul obat penanganan pertama gejala anemia? Kemudian dengan tidak dimasak, apakah kandungan zat besi yang ada di dalam kelakai bisa lebih tinggi di bandingkan kelakai yang dimasak?

\section{METODE PENELITIAN}

Metode yang digunakan dalam penulisan karya tulis ini adalah deskriftif. Penulis hanya menganalisis fakta-fakta yang sudah ada dalam kehidupan seharihari masyarakat sekitar tentang cara mengatasi anemia dengan memanfaatkan tumbuhan kelakai.

\section{HASIL PENELITIAN DAN PEMBAHASAN}

Kelakai termasuk tumbuhan yang gampang dan cepat beradaptasi dengan alam sehingga bisa tumbuh dimana saja, seperti di batang-batang pohon, kayukayu yang sudah lapuk maupun lahan kering, tapi kelakai akan tumbuh subur di lahan bergambut karena intensitas air yang cukup banyak sehingga memudahkan perkembangbiakannya.

Paku yang hidup di tanah, menjalar panjang hingga 5-10 m. Daun-daun terbagi menjadi dua bentuk, steril dan fertil. Keduanya memiliki panjang antara 40-80 cm, dengan tangkai $15-20 \mathrm{~cm}$ dan 8-15 pasang anak daun, serta satu anak daun terminal. Anak-anak daun laterai biasanya memiliki pelebaran serupa cuping telinga di pangkalnya, yang tidak dimiliki oleh anak daun ujung; anak-anak daun di bagian atas (mendekati ujung) biasanya kecil. Tulang daun utama dengan alur (lekukan) di sisi atasnya. Anak-anak daun pada daun steril bertangkai pendek; 
bentuk jorong sempit, biasanya 15 × $3 \mathrm{~cm}$, meski selalu bervariasi ukurannnya; halus, mengkilap, hijau gelap, pucat di sisi bawah; tepinya bergerigi; dengan kelenjar di tepi anak daun dekat pangkal. Tumbuh hingga pada ketinggian 900 mpdl dan merambat pada hutan-hutan bekas penebangan kayu terutama dekat air tawar, air payau, hutan bakau, di tanah pasir, khususnya di sepanjang tepi sungai dan sumber air. Paku ini di dapati di dataran rendah, di tempat terbuka dan hutan sekunder, dan umum ditemukan di wilayah rawa-rawa termasuk rawa gambut.

Salah satu kandungan dalam kelakai adalah zat besi. Kandungan besi dalam kelakai cukup tinggi. Mineral besi $(\mathrm{Fe})$ sendiri berfungsi untuk membentuk hemoglobin yang membawa oksigen dari paru-paru keseluruh tubuh. Sehingga kelakai dapat digunakan sebagai pangan fungsional penambah darah. (Hayinah, dkk. 2013).

Zat besi atau $\mathrm{Fe}$ adalah nutrisi penting untuk tubuh manusia. Zat besi adalah salah satu unsur yang diperlukan dalam proses distribusi oksigen dalam darah manusia. Zat besi juga berfungsi dalam proses produksi hemoglobin. Kekurangan zat besi akan semakin memperbesar potensi tubuh kekurangan asupan darah yang dapat menyebabkan anemia. Tanpa zat gizi, pembentukan sel darah merah akan berjalan lambat dan tidak mencukupi, dan selnya bisa memiliki kelainan bentuk dan tidak mampu mengangkat oksigen sebagaimana mestinya.

Anemia didefinisikan sebagai suatu keadaan dimana rendahnya konsentrasi hemoglobin $(\mathrm{Hb})$ atau hematokrit (perbandingan sel darah merah terhadap volume darah) berdasarkan nilai ambang batas yang disebabkan oleh rendahnya produksi sel darah merah (eritrosit) dan hemoglobin. Anemia merupakan suatu kondisi dimana kadar hemoglobin atau berkurangnya jumlah eritrosit dalam $1 \mathrm{~mm} 3$ darah atau kurangnya volume sel darah merah yang memadati dalam $100 \mathrm{ml}$ darah (darah kurang dari ukuran normal). Hal ini disebabkan karena kekurangan pasokan zat gizi $(\mathrm{Fe})$ yang merupakan inti molekul hemoglobin sebagai unsur utama sel darah merah. Zat besi merupakan senyawa paling penting sebagai penyusun hemoglobin (sel darah merah), tubuh membutuhkan zat besi sekitar 1 - 3,2 mg per hari. (Citrakesumasari, 2012)

Hasil analisis mineral Fe menunjukkan rata-rata Fe di daun kelakai lebih tinggi sebesar 291,3158 mg per $100 \mathrm{mg}$, dibandingkan di batang kelakai 221,4427 mg per $100 \mathrm{mg}$. Fe merupakan salah satu komponen penyusun pigmen yang ada pada daun kelakai.

Secara spesifik, kelakai yang digunakan oleh suku dayak untuk mengobati anemia belum pernah diteliti, tetapi memberikan bukti yang nyata secara empiris (etnobotani). Kelakai berkhasiat mencukupi Fe pada ibu menyusui dan balita, pereda demam, mengobati sakit kulit, dan juga sebagai pencuci perut.

Kelakai sebagai solusi dari kekurangan zat besi dapat diolah dalam bentuk kapsul melalui proses pengeringan terhadap kelakai. Pengeringan adalah proses perpindahan massa air atau pelarut lainnya dari suatu zat padat atau semi padat dengan menggunakan penguapan. Kelakai yang telah dikeringkan akan menjadi padat dalam wujud bubuk maupun potongan besar. Proses yang di lakukan pertama adalah dengan membasuh kelakai hingga bersih dan dilanjutkan dengan proses pengeringan di bawah sinar matahari sampai kelakai benar-benar rapuh kemudian didinginkan beberapa saat dan tumbuk kelakai hingga halus dilanjutkan dengan memasukkan kelakai yang telah halus ke dalam kapsul. 
Penulis belum melakukan uji terhadap kelakai yang dimasak atau kelakai yang dikeringkan (dibuat kapsul), manakah yang kandungan Fe nya yang lebih banyak. Jadi penelitian ini harus dilanjutkan lagi untuk mengetahui perlakuan yang terbaik untuk memanfaatkan kelakai guna penanganan pertama gejala anemia.

\section{SIMPULAN}

Dari penelitian ini dapat diambil beberapa kesimpulan, yaitu: penelitian ini membuktikan bahwa kandungan di dalam kelakai berupa Fe dapat mengatasi penyakit anemia. Kelakai dapat dikonsumsi dengan cara dimasak menjadi lauk, dapat juga diaplikasikan dalam bentuk kapsul.

Bahan pembuatan kapsul antianemia adalah kalakai dengan menggunakan proses pengeringan. Benda yang telah dikeringkan akan menjadi padat dalam wujud bubuk maupun potongan besar. Proses yang di lakukan pertama adalah dengan membasuh kelakai hingga bersih dan dilanjutkan dengan proses pengeringan di bawah sinar matahari sampai kelakai benar-benar rapuh kemudian dinginkan beberapa saat dan tumbuk kelakai hingga halus dilanjutkan dengan memasukkan kelakai yang telah halus ke dalam kapsul.

Penelitian ini harus dilanjutkan lagi untuk mengetahui perlakuan yang terbaik untuk memanfaatkan kelakai guna penanganan pertama gejala anemia.

\section{DAFTAR RUJUKAN}

Citrakesumasari, Prof, DR. 2012. Anemia Gizi Masalah dan Pencegahannya. KALIKA, Sleman.

Hayinah, dkk. 2013. Jurnal : Studi Potensi Kalakai (Stenochlaena Palustris), Sebagai Pangan Fungsional. UNLAM, Banjarmasin. (online). http://ppjp.unlam.ac.id, diakses tanggal 7 November 2017

Ide, Pangkalan. 2007. Seri Diet Korektif Diet Atkins. PT. Elex Media Komputindo Kelompok Gramedia, Jakarta

Wikipedia. 2017. Lemidi. (online) https://id.wikipedia.org/wiki/Lemidi, diakses tanggal 7 November 2017

Wikipedia. 2017. Zat Besi. (online) https://id.m.wikipedia.org/wiki/Zat-besi, diakses tanggal 7 November 2017 